\title{
Mini tomato production in organic system under greenhouse with partial control of meteorological elements
}

\author{
Haroldo F. de Araujo ${ }^{1}$, Paulo A. M. Leal ${ }^{1}$, Thais Q. Zorzeto ${ }^{1}$, Eduardo F. Nunes ${ }^{1} \&$ Pâmela S. Betin ${ }^{1}$ \\ ${ }^{1}$ Universidade Estadual de Campinas/Faculdade de Engenharia Agrícola. Campinas, SP. E-mail: haroldfa@gmail.com (Corresponding author); \\ pamleal@feagri.unicamp.br; thaisqz@uol.com.br; nunes.r4f@gmail.com; pamela_betin@hotmail.com
}

\section{Key words:}

Solanum lycopersicum L.

organic cultivation

evaporative cooling

forms of cultivation

automated control

\begin{abstract}
A B S T R A C T
The objective of this research was to evaluate the meteorological elements of the environments and the production components of mini tomato crop in organic system in different forms of cultivation, biofertilizer doses and technological levels of protected environments. The research was conducted in completely randomized design in a $3 \mathrm{x}$ $2 \times 5$ factorial scheme, corresponding to three greenhouses (A - climatized, B - mobile screen and $\mathrm{C}$ - fixed screen), two forms of cultivation (pots and beds) and five doses of a commercial biofertilizer $(0,50,100,150$ and $200 \%$ of dose indicated), with five replicates. The treatments affected the analyzed variables, except for biofertilizer doses and interaction of treatments. Air temperature was unchanged among the environments and the mean and minimum relative humidity were within the control range in the climatized greenhouse. The greenhouse with mobile screen showed the best production results for the cultivation in beds and the biofertilizer doses were indifferent for all treatments.
\end{abstract}

\section{Palavras-chave:}

Solanum lycopersicum L. cultivo orgânico resfriamento evaporativo formas de cultivo controle automatizado

\section{Produção de minitomate em sistema orgânico sob ambientes protegidos com controle parcial de elementos meteorológicos}

\section{R E S U M O}

Objetivou-se, nesta pesquisa, avaliar os elementos meteorológicos dos ambientes e os componentes de produção da cultura do tomateiro minitomate, em sistema orgânico de produção em diferentes formas de cultivo, doses de biofertilizante e graus tecnológicos de ambientes protegidos. A pesquisa foi conduzida em delineamento inteiramente casualizado em esquema fatorial $3 \times 2 \times 5$ constituído de três casas de vegetação (A - climatizada, B - tela móvel e C - tela fixa) duas formas de cultivo (vasos e canteiros) e cinco doses de biofertilizante comercial $(0,50,100,150$ e $200 \%$ da dose indicada pelo fabricante) com cinco repetições. Os tratamentos influenciaram as variáveis analisadas, exceto para as doses de biofertilizante e interação dos tratamentos. A temperatura do ar se manteve inalterada entre os ambientes e a umidade relativa média e mínima dentro da faixa de controle na casa de vegetação climatizada. A casa de vegetação com tela móvel apresentou os melhores resultados produtivos na forma de cultivo em canteiros ficando as doses de biofertilizante indiferentes a todos os tratamentos. 


\section{INTRODUCTION}

The global sales of organic food and beverages increase every year, reaching approximately US\$ 80 billions in 2014 (Willer \& Lernoud, 2016). According to these authors, Brazil is among the largest global producers and exporters of these foods. However, the importance of Brazil in this market is still limited to some crops, but the productive potential of crops such as tomato, which has great importance in the national economy (Shirahige et al., 2010), is high. Such importance places its production in the first position in value and volume among the vegetables cultivated in Brazil, accounting for about 4.29 million tons in 2014 (IBGE, 2013), the eighth largest global producer according to FAO (2013).

Given the susceptibility of the crop to external (climatic) and phytosanitary factors (Maciel \& Silva, 2014), the protected cultivation of tomato has expanded in the last years in order to better control such factors and increase yield, quality and regularity of production (Reis et al., 2013). Outside this system, the crop shows higher yield under conventional cultivation, in comparison to organic cultivation (Seufert et al., 2012), but with the advantage of requiring a reduced amount of nutrients and energy (Zandonadi et al., 2014). However, studies on its production in protected environments under the climatic conditions of Brazil are mostly conducted in environments with some static or fixed meteorological control. Therefore, the protection of crops is almost exclusively limited to the "umbrella effect" (Bliska Júnior, 2011), and the edaphoclimatic requirements of the crops remain with no manual or automated control through intelligent systems (Teruel, 2010). Thus, this study aimed to evaluate meteorological conditions, yield and technical indicators of production of mini tomato in organic system under different forms of cultivation, biofertilizer doses and technological levels of protected environments.

\section{Material AND Methods}

The research was carried out from February to November 2013, in three greenhouses installed at the experimental field of the Faculty of Agricultural Engineering (FEAGRI) of the State University of Campinas (UNICAMP). The greenhouses were installed parallel to each other, with equal form and volume, total area of $70.40 \mathrm{~m}^{2}(6.4 \times 11 \mathrm{~m})$ and ceiling height of $3.0 \mathrm{~m}$. The gable roofs of all greenhouses were covered with a 150 - $\mu \mathrm{m}$-thick light-diffusing milky plastic.

The greenhouses $(\mathrm{GH})$ were referred to as GHA and GHB. GHA was climatized, totally closed with $150-\mu$ m-thick light-diffusing milky plastic and equipped with automatic control systems based on crop edaphoclimatic requirements, mechanical ventilation, evaporative cooling and mobile thermo-reflective screen. The mechanical ventilation consisted of an exhauster (ED24) installed above the ceiling height level, activated by a temperature sensor (SHT-75, precision $\pm 0.3{ }^{\circ} \mathrm{C}$ ) installed in the geometric center $(3 \mathrm{~m})$, which was turned on when temperature reached $26 \pm 2{ }^{\circ} \mathrm{C}$ and turned off when it reached $24 \pm 2{ }^{\circ} \mathrm{C}$.

The evaporative cooling system consisted of: (1) one porous medium $\left(\mathrm{CelDek}^{\otimes}\right)$, installed in the south face $(0.5$ $\mathrm{m})$, with dimensions of $6.4 \times 1.5 \times 0.15 \mathrm{~m}$, humidified by a closed water circulation system, activated by a centrifuge pump (1.0 hp) with flow rate of $\left(7,000 \mathrm{~L} \mathrm{~h}^{-1}\right)$, interconnected to a 500-L tank; (2) an exhauster (EM30), installed in the north face $(1.10 \mathrm{~m})$, activated by a temperature and relative air humidity sensor (SHT-75, precision $\pm 0.3{ }^{\circ} \mathrm{C}$ and $\pm 1.8 \%$ ), installed in the geometric center $(2 \mathrm{~m})$. The control logic was based on the following programming: air temperature $>28^{\circ} \mathrm{C}$ and/or relative air humidity $<65 \%$, exhauster and centrifuge pump were turned on, first the exhauster and, after $1 \mathrm{~min}$, the centrifuge pump; when the relative air humidity reached $75 \%$, the pump was turned off and, $5 \mathrm{~min}$ later, if the temperature was not $>28^{\circ} \mathrm{C}$, the exhauster (EM30) was turned off, hysteresis $\left( \pm 2{ }^{\circ} \mathrm{C}\right.$ and $\left.\pm 10 \%\right)$.

An aluminized thermo-reflective screen with $50 \%$ of wave transmissivity (aluminet) was installed $(2.60 \mathrm{~m})$ in all greenhouses and moved by a system of bearings and pulleys activated by a reverse motor. A global radiation sensor (LI-200SA) was installed at the plant canopy height for motor automation, according to the following control logic: (nocturnal) from $18 \mathrm{~h}$ to $5 \mathrm{~h}$ and $59 \mathrm{~min}$, the screen was opened and remained open during the night period; (diurnal) from $6 \mathrm{~h}$ to $17 \mathrm{~h}$ and $59 \mathrm{~min}$, the activation occurred through the global radiation (GR); GR $\geq 300 \mathrm{~W} \mathrm{~m}^{-2}$, the screen was opened and remained for $10 \mathrm{~min}$ for sensor reading; $\mathrm{GR}<300 \mathrm{~W} \mathrm{~m}^{-2}$, the screen was closed.

The greenhouses $\mathrm{B}$, with mobile screen (GHB), and C, with fixed screen (GHC), had their sides closed with an anti-aphid screen (baby citrus) $(0.003 \times 0.008 \mathrm{~m}$ mesh), equipped with a thermo-reflective screen in mobile system in B and fixed system in $\mathrm{C}$. The programming for opening and closing the screen in GHB followed the hour pattern of: at $6 \mathrm{~h}$, closed (retract) and at $10 \mathrm{~h}$, opened (extended); at $16 \mathrm{~h}$, closed and at $18 \mathrm{~h}$ opened and remained open until $6 \mathrm{~h}$. In cloudy days, the screen was manually retracted to allow the incidence of solar radiation.

The production environments were meteorologically characterized using sensors of temperature and relative air humidity (SHT-75), installed in the geometric center (2 m), with wireless communication (arduino protocol), while the external environment was characterized by a weather station close to the greenhouses. Monitoring, data collection of the sensors and automation of the equipment were performed using a free supervisory software (ScadaBR), with actuation node functioning according to the control logics.

The greenhouses were cultivated with tomatoes of the group of mini tomatoes, cultivar 'Carolina' (Feltrin), which have indeterminate growth. The seedlings were produced in loco, irrigated, in a greenhouse using trays of $0.050 \mathrm{~L} \mathrm{cell}^{-1}$.

At 35 days after sowing, the seedlings were transplanted, in a single-row scheme, at spacing of $0.9 \times 0.5 \mathrm{~m}(2.2$ plant $\left.\mathrm{m}^{-2}\right)$, to pots $(15 \mathrm{~L})$ and beds $(0.4 \times 0.2 \times 5.5 \mathrm{~m})$, filled with soil collected in an area without cultivation.

Liming was performed according to soil analysis (Table 1), increasing base saturation to $80 \%, 40$ days before transplanting.

The basal fertilization of beds and pots were performed according to the recommendation for the staked tomato and the soil analysis, through the application of $2.0 \mathrm{~kg}$ of bovine manure (wet weight), $0.20 \mathrm{~kg}$ of the compound bio-bokashi, $0.30 \mathrm{~kg}$ of 
Table 1. Physico-chemical analysis of soil

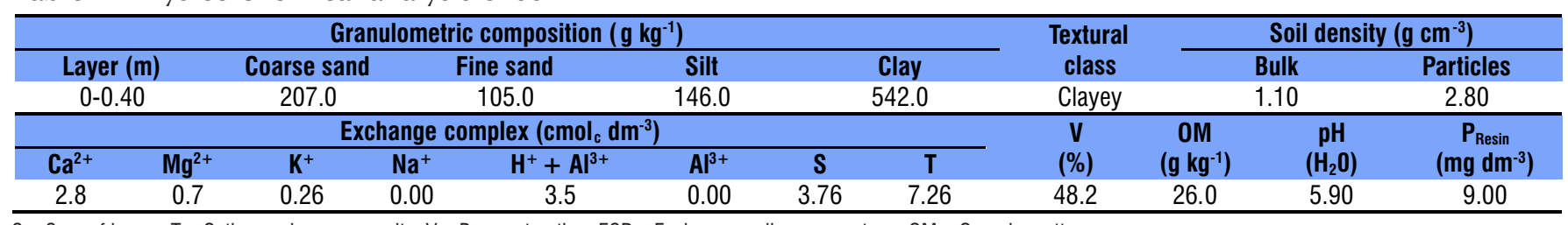

S - Sum of bases; T - Cation exchange capacity; $V$ - Base saturation; ESP - Exchange sodium percentage; OM - Organic matter

thermo-phosphate, $0.027 \mathrm{~kg}$ of potassium sulfate and $0.10 \mathrm{~kg}$ of FTE Br 12 per linear meter of bed, which were incorporated forty days before transplanting. In the pots, the amounts applied in the beds were divided according to the number of plants per linear meter. The bovine manure and the bio-bokashi showed the following chemical characteristics (Table 2).

Top-dressing fertilizations followed the adaptation of the methodology used by Libânio (2010) and the soil analysis, distributed over time according to the crop phenological stages (Table 3 ) and started in intervals of 10 days, until the $70^{\text {th }}$ day, when the fertilizations with the compound were suspended due to the high vegetative growth of the plants, returning 35 days after, based on the data of the relative chlorophyll index of the leaves. Thus, the mean intervals of applications of the compound were equal to 35 days, until the end of the cycle, and the fertilizations with potassium sulfate applied at intervals of 2 days through fertigation (ready solution at $2.5 \mathrm{mS} \mathrm{cm}^{-1}$ ), according to the management automation of irrigation applied at 7 a.m.; this solution was prepared at mean intervals of 8 days in a $500-\mathrm{L}$ tank.

The plants were trained using two stakes and a ribbon, under a wire installed above the planting rows attached to bamboo posts, until the 184 DAT. Tip pruning was performed when plants were approximately $6 \mathrm{~m}$ long.

Irrigation was performed through a localized system using in-line drippers with flow rate of $2 \mathrm{~L} \mathrm{~h}^{-1}$, spaced by $0.50 \mathrm{~m}$ in the pots and $0.25 \mathrm{~m}$ in the beds, automatically activated by a controller (8059 9S), according to the water demand of each greenhouse. Irrigation management was defined based on the water percolation of specific pots (6 pots), performed every 7 days until 21 DAT and then every 14 days. According to this management, irrigation pulses previously defined based on the periods of highest evaporative demand of plants and soil $(7,11$, and $13 \mathrm{~h}$ and $30 \mathrm{~min}$ and $16 \mathrm{~h}$ ) were increased, totaling actual water consumptions of 135.12, 171.95 and 154.29 (L plant cycle $^{-1}$ ), applied in the greenhouses A, B and C, respectively.

The meteorological elements of the environments, temperature and relative air humidity (minimum, mean and maximum), were evaluated in a randomized block design with four treatments (environments A, B, C and external) and eight replicates. Production components were evaluated in a randomized block design, in $3 \times 2 \times 5$ factorial scheme ( 3 greenhouses $\mathrm{x} 2$ forms of cultivation - beds and pots $\mathrm{x} 5$ doses of biofertilizer - 0, 50, 100, 150 and 200\%) and 5 replicates. A commercial biofertilizer called Microgeo $^{\star}$ (Table 4) was prepared and applied according to the specifications of the manufacturer, with reference dose of $150 \mathrm{~L} \mathrm{ha}^{-1}$ (adopting the treatment of $100 \%$ as corresponding to $5.25 \mathrm{~mL} \mathrm{plant}^{-1}$ ) for weekly applications in vegetables.

Fruit harvest started at 91 DAT and was performed at mean intervals of 4 to 7 days, continuing until the end of the production cycle, 245 DAT. Total and marketable yields were evaluated, besides the technical parameters (number of fruits per plant and per raceme, mean mass of fruits and total shoot dry matter). The meteorological elements, temperature and relative air humidity (minimum, mean and maximum), were evaluated only with the monthly means, and the maximum and minimum values were based on the means of the ten lowest or highest consecutive data, respectively.

The variables were subjected to analysis of variance and comparison of means by Tukey test at 0.05 probability using the program Assistat, Beta version 7.7, 2012.

Table 2. Chemical characteristics of the bovine manure and the bio-bokashi compound

\begin{tabular}{|c|c|c|c|c|c|c|c|c|c|c|c|c|c|c|}
\hline \multicolumn{6}{|c|}{ Macronutrients (\%) } & \multicolumn{5}{|c|}{ Micronutrients (ppm) } & $\mathrm{OM}$ & $\bar{U}$ & \multirow{2}{*}{$\mathrm{C} / \mathrm{N}$} & \multirow{2}{*}{$\mathrm{pH}$} \\
\hline $\mathbf{N}$ & $\mathrm{P}_{2} \mathrm{O}_{5}$ & $\mathrm{~K}_{2} \mathrm{O}$ & $\mathrm{Ca}$ & $\mathrm{Mg}$ & $S$ & $\mathbf{M n}$ & $\mathrm{Cu}$ & $\mathrm{Zn}$ & B & $\mathrm{Na}$ & \multicolumn{2}{|c|}{ (\%) } & & \\
\hline 1.30 & 0.78 & 0.45 & 0.85 & 0.27 & 0.34 & 190 & 38 & 135 & 230 & 540 & 19 & 23 & $8 / 1$ & 6.4 \\
\hline \multicolumn{15}{|c|}{ Analysis of bio-bokashi } \\
\hline 3.45 & 2.65 & 1.48 & 1.90 & 0.90 & 0.40 & 370 & 15 & 70 & 250 & 395 & 80.42 & 9.65 & $13 / 1$ & 5.5 \\
\hline
\end{tabular}

$\mathrm{OM}$ - organic matter, $\mathrm{U}$ - water content; $\mathrm{C} / \mathrm{N}$ - carbon/nitrogen ratio

Table 3. Amounts of fertilizers applied as top-dressing

\begin{tabular}{|c|c|c|c|c|c|c|c|c|c|c|c|c|c|c|c|c|c|c|c|c|}
\hline \multirow{2}{*}{ Nutrients } & \multirow{2}{*}{$\begin{array}{c}\text { TA } \\
\left(\mathrm{kg} \mathrm{ha}^{-1}\right)\end{array}$} & \multicolumn{19}{|c|}{ Days after transplanting (DAT) } \\
\hline & & 10 & 20 & 30 & 40 & 50 & 60 & 70 & 80 & 88 & 96 & 104 & 105 & 112 & 140 & 169 & 175 & 210 & 218 & 227 \\
\hline $\mathrm{N}$ & 200 & 26 & 26 & 26 & 26 & 15 & 15 & 15 & 0 & 0 & 0 & 0 & 30 & 0 & 30 & 0 & 30 & 30 & $x$ & $x$ \\
\hline $\mathrm{K}_{2} \mathrm{O}$ & 450 & 26 & 26 & 50 & 75 & 75 & 55 & 50 & 30 & 30 & 20 & 15 & 0 & 13 & & 13( & very 8 & ays) & & 13 \\
\hline
\end{tabular}

TA - Total amount

Table 4. Chemical characterization of the biofertilizer

\begin{tabular}{|c|c|c|c|c|c|c|c|c|c|c|c|c|c|c|c|}
\hline \multicolumn{7}{|c|}{ Macronutrients $\left(\mathrm{mg} \mathrm{L}^{-1}\right)$} & \multicolumn{7}{|c|}{ Micronutrients (mg L ${ }^{-1}$ ) } & \multirow{2}{*}{$\mathrm{pH}$} & \multirow{2}{*}{$\begin{array}{c}E C \\
\left(\mathrm{dS} \mathrm{m}^{-1}\right)\end{array}$} \\
\hline $\mathrm{NO}_{3}^{-}$ & $\mathbf{P}$ & $\mathrm{Cl}^{-}$ & $S$ & $\mathrm{NH}_{4}^{+}$ & $\mathrm{K}^{+}$ & $\mathrm{Ca}$ & $\mathrm{Na}$ & $\mathrm{Mg}$ & B & $\mathrm{Cu}$ & $\mathrm{Fe}$ & $\mathrm{Mn}$ & $\mathrm{Zn}$ & & \\
\hline 4.46 & 5.90 & 95.85 & 6.94 & 2.06 & 238.75 & 27.00 & 52.40 & 10.96 & 0.19 & 0.02 & 1.92 & 0.33 & 0.03 & 7.10 & 0.80 \\
\hline
\end{tabular}

EC - Electrical conductivity 


\section{Results AND Discussion}

The monthly means of minimum, mean and maximum air temperature (Table 5) observed during the research showed no statistical influence between the cultivation environments, certainly due to the effects of the technologies used for partial control, besides the period of cultivation (autumn and winter). However, mean and maximum air temperatures remained within the range considered as adequate for the crop (22 to 30 ${ }^{\circ} \mathrm{C}$ ) in all production environments.

Duarte et al. (2011), evaluating alterations in air temperature due to the use of screens on the sides of protected environments cultivated with tomato, observed that environments covered with transparent plastic (low-density polyethylene - LDPE) during autumn-winter and side covering with anti-aphid screen promoted thermal gain to the environment.

Unlike air temperature, only the maximum relative humidity did not differ statistically between the environments, remaining virtually at the maximum limit of $100 \%$ in all environments, which favored the occurrence of fungal diseases, especially in GHA. According to Caliman et al. (2005), with relative humidity reaching $100 \%$, there are the processes of water vapor condensation on the internal surface of the greenhouse cover and formation of dew on the leaves, causing their wetting, which favors the infection and spread of diseases and may cause large production losses.

Minimum and mean relative humidity were more critical in the external environment. The greenhouses B and C, due to the control of relative humidity, recorded statistically equal means, but above that recorded in the external environment, especially because of plant evapotranspiration and the evaporation of the applied irrigation water. In GHA, the control promoted by the evaporative cooling system maintained the values of minimum and mean relative humidity within the adequate limits for the crop (50 to 70\%). Similar variations of relative humidity and air temperature were observed by Silva et al. (2013), in tomato production in a protected environment, comprehending the same production period (autumn-winter), under the meteorological conditions of the Paraíba state.
Based on the analysis of variance of the production components, it was observed that the treatments influenced the analyzed variables and their interactions did not show significant difference, as well as the treatments with the biofertilizer doses.

This lack of significance of the biofertilizer may be related to the amount of organic matter present in the soil and addition of bovine manure and bio-bokashi, which mineralized, masking the effects of the biofertilizer on the plants, as observed by Oliveira et al. (2013), evaluating the application of biofertilizer through the soil.

According to the means of the treatments (Table 6), the GHB showed the best results for all analyzed variables; however, it only did not differ from GHA for the variable mean mass of fruits. Total and marketable yields and total dry matter were not different between greenhouses A and B, despite the statistical differences for the variables number of fruits per plant, per raceme and mean mass of fruits. For Azevedo et al. (2010), these variables are of great importance in the quantification of the production, considering their simultaneous dependence for the increase in crop yield. Max et al. (2009), working with protected environments, screened (SC) and closed with plastic and evaporative cooling system (EC) in Thailand, observed commercial yield (CY) significantly higher in SC $\left(4.5 \mathrm{~kg} \mathrm{plant}^{-1}\right)$ against $\left(3.8 \mathrm{~kg} \mathrm{plant}^{-1}\right)$ in EC. These authors concluded that, in regions with high relative air humidity, the use of evaporative cooling system without technical modifications that allow de dehumidification of the environment does not improve tomato yield in protected cultivation.

Cultivation in beds showed the best results of production, except for the variables numbers of fruits per plant and per raceme. The number of fruits was higher than that observed by Rocha et al. (2010), who obtained 137 fruits plant ${ }^{-1}$ working with the hybrid Blue Line in a protected environment in conventional system.

In general, the greenhouse $\mathrm{B}$, associated with the production in beds, showed the best increments of production, which is certainly related to the meteorological benefits promoted by the movement of the thermo-reflective screen along the day,

Table 5. Means of air temperature and relative humidity in the different environments

\begin{tabular}{|c|c|c|c|c|c|c|}
\hline \multirow{2}{*}{ Environments } & $T_{\min }$ & $T_{m}$ & $T_{\max }$ & $\mathrm{RH}_{\min }$ & $\mathrm{RH}_{\mathrm{m}}$ & $\mathrm{RH}_{\max }$ \\
\hline & \multicolumn{3}{|c|}{$\left({ }^{\circ} \mathrm{C}\right)$} & \multicolumn{3}{|c|}{$(\%)$} \\
\hline Greenhouse A & $13.12 \mathrm{a}$ & $20.56 \mathrm{a}$ & $29.29 a$ & $62.78 \mathrm{a}$ & $85.49 a$ & $96.19 \mathrm{a}$ \\
\hline Greenhouse B & $13.08 \mathrm{a}$ & $20.55 \mathrm{a}$ & $29.63 \mathrm{a}$ & $47.45 \mathrm{~b}$ & $77.28 \mathrm{~b}$ & $96.75 \mathrm{a}$ \\
\hline Greenhouse C & $13.13 \mathrm{a}$ & $20.69 a$ & $30.16 \mathrm{a}$ & $43.39 \mathrm{~b}$ & 74.97 b & $95.47 \mathrm{a}$ \\
\hline External D & $13.27 \mathrm{a}$ & $20.26 \mathrm{a}$ & $29.29 \mathrm{a}$ & $36.08 \mathrm{c}$ & 69.40 c & $96.39 \mathrm{a}$ \\
\hline Means & 13.15 & 20.51 & 29.59 & 47.42 & 76.79 & 96.20 \\
\hline CV (\%) & 6.35 & 3.76 & 3.89 & 15.51 & 6.68 & 2.57 \\
\hline
\end{tabular}

Means followed by the same letter in the columns do not differ statistically by Tukey test ( $p>0.05) ; T_{\min }-$ Minimum temperature; $T_{m}-$ Mean temperature; $T_{\max }-$ Maximum temperature; $\mathrm{RH}_{\min }$ - Minimum relative humidity; $\mathrm{RH}_{\mathrm{m}}-$ Mean relative humidity; $\mathrm{RH}_{\max }-$ Maximum relative humidity

Table 6. Means of the production components as a function of the production environments and forms of cultivation

\begin{tabular}{|c|c|c|c|c|c|c|}
\hline Treatments & TY & CY & Fruits plant $^{-1}$ & $\begin{array}{l}\text { Mean mass } \\
\text { of fruits }(\mathrm{g})\end{array}$ & Fruits raceme ${ }^{-1}$ & $\begin{array}{c}\text { Total dry matter } \\
\text { (g) }\end{array}$ \\
\hline Greenhouse A & $3.86 \mathrm{~b}$ & $3.68 b$ & $189.56 \mathrm{c}$ & $8.72 \mathrm{a}$ & $4.36 \mathrm{C}$ & $441.96 \mathrm{~b}$ \\
\hline Greenhouse B & $4.46 \mathrm{a}$ & $4.25 \mathrm{a}$ & $221.42 \mathrm{a}$ & $8.63 \mathrm{a}$ & $5.12 \mathrm{a}$ & $501.97 \mathrm{a}$ \\
\hline Greenhouse C & $3.85 b$ & $3.67 \mathrm{~b}$ & $205.91 \mathrm{~b}$ & $7.98 \mathrm{~b}$ & $4.76 \mathrm{~b}$ & $427.33 \mathrm{~b}$ \\
\hline Beds & $4.21 \mathrm{a}$ & $4.01 \mathrm{a}$ & $207.13 \mathrm{a}$ & $8.69 \mathrm{a}$ & $4.82 \mathrm{a}$ & $496.39 \mathrm{a}$ \\
\hline Pots & $3.91 \mathrm{~b}$ & $3.72 b$ & $204.12 \mathrm{a}$ & $8.19 b$ & $4.66 \mathrm{a}$ & $417.78 \mathrm{~b}$ \\
\hline CV (\%) & 17.86 & 17.54 & 14.14 & 5.51 & 15.91 & 15.50 \\
\hline
\end{tabular}

TY - Total yield; CY - Commercial yield; Means followed by the same letter in the columns do not differ statistically by Tukey test ( $p>0.05)$ 
reducing the excess of solar radiation and the consequent increase in photosynthetic rate (Andriolo, 1999).

Comparing the results of the research with those of national and international literature, these authors showed the relevance for the production system, and the results were higher than those found by Toledo et al. (2011) and Azevedo et al. (2010), who observed yields of 0.677 and $1.0 \mathrm{~kg} \mathrm{~m}^{-2}$, respectively, both in organic system at the field.

Guilherme et al. (2014), working with the same cultivar ('Carolina') and production system, observed mean of 64 fruits plant $^{-1}$ and total yield of about $5.39 \mathrm{~kg} \mathrm{~m}^{2}$ for the diameter between 25 and $30 \mathrm{~mm}$; however, these authors observed mean mass of fruits of $30.0 \mathrm{~g}$, approximately 3.5 times higher than that observed in the present study $(8.50 \mathrm{~g})$, certainly due to the use of a cultivar with different production characteristics.

Production data of long-life tomatoes in protected environment with $50 \%$ shade screen on the sides, obtained by Reis et al. (2013) with conventional fertilization management, showed yield of $4.92 \mathrm{~kg} \mathrm{~m}^{-2}$, a value close to that found in the present study, but low, considering the mean mass of fruits (158.14 g) and fertilization management. Leyva et al. (2013) observed mean yield of $1.10 \mathrm{~kg} \mathrm{~m}^{-2}\left(2.20\right.$ plants $\left.\mathrm{m}^{-2}\right)$ and mean mass of $11.85 \mathrm{~g}_{\text {fruit }}^{-1}$ in greenhouse with meteorological control using shade screens, for the production of mini tomatoes in a conventional system in Spain. These values are lower than those found in the present study, even considering the mean of the three greenhouses $\left(3.869 \mathrm{~kg} \mathrm{~m}^{-2}\right)$.

\section{Conclusions}

1. Air temperature remained without significant difference between the environments and the mean and minimum relative humidity remained within the control range in the climatized greenhouse.

2. The greenhouse with time control of the thermoreflective screen showed the best production results.

3. The form of cultivation in beds guaranteed the best results for the variables commercial yield, mean mass of fruits and total shoot dry matter.

4. The application of doses of the biofertilizer Microgeo through the soil did not lead to production increments in the cultivation of organic tomato.

\section{ACKNowledgments}

To the State University of Campinas (UNICAMP), Faculty of Agricultural Engineering (FEAGRI); to the São Paulo Research Support Foundation (FAPESP); the National Council for Scientific and Technological Development (CNPq); the Coordination for the Improvement of Higher Education Personnel (Capes); the Student Support Service of the UNICAMP (SAE/UNICAMP) and the companies R4F, Equipesca, ElectroPlastic, Microgeo, Hidrogood, Netafim, JKS Bandejas and Polysack.

\section{Literature Cited}

Andriolo, J. L. Fisiologia das culturas protegidas. Santa Maria: UFSM, 1999. 142p.
Azevedo, V. F.; Abboud, A. C. S.; Carmo, M. G. F. Row spacing and pruning regimes on organically grown cherry tomato. Horticultura Brasileira, v.28, p.389-394, 2010. http://dx.doi. org/10.1590/S0102-05362010000400002

Bliska Júnior, A. Manejo de ambientes protegidos: Estufas e casas de vegetação. Revista Casa da Agricultura, v.14, p.6-42, 2011.

Caliman, F. R. B.; Silva, D. J. H.; Fontes, P. C. R.; Stringheta, P. C.; Moreira, G. R.; Cardoso, A. A. Avaliação de genótipos de tomateiro cultivados em ambiente protegido e em campo nas condições edafoclimáticas de Viçosa. Horticultura Brasileira, v.23, p.255259, 2005. http://dx.doi.org/10.1590/S0102-05362005000200018

Duarte, L. A.; Schöffel, E. R.; Mendez, M. E. G.; Schallenberger, E. Alterações na temperatura do ar mediante telas nas laterais de ambientes protegidos cultivados com tomateiro. Revista Brasileira de Engenharia Agrícola e Ambiental, v.15, p.148-153, 2011. http:// dx.doi.org/10.1590/S1415-43662011000200006

FAO - Food and Agriculture Organization of the United Nations. Production: Brasil, 2013. <http://faostat.fao.org/site/339/default. aspx>. 20 Fev. 2014.

Guilherme, D. O.; Costa, C. A.; Sampaio, R. A.; Martins, E. R.; Silveira, H. R. O.; Valadares, S. V.; Fernandes, S. G. Comparison between cherry tomato in the organic system of cultivation under different spacing. Academia Journal of Agricultural Research, v.2, p.23-29, 2014. http://dx.doi.org/10.15413/ajar.2013.0145

IBGE - Instituto Brasileiro de Geografia e Estatísticas. Quantidade produzida e área colhida da lavoura temporária. Tomate. Produção agrícola municipal, 2013. <http://www.sidra.ibge.gov.br/bda/ tabela/listabl.asp?c=1618\&z=t\&o=26>. 14 Mar. 2015.

Leyva, R.; Constán-Aguilar, C.; Blasco, B.; Sánchez-Rodríguez, E.; Romero, L.; Soriano, T.; Ruíz, J. M. Effects of climatic control on tomato yield and nutritional quality in Mediterranean screenhouse. Journal of the Science of Food and Agriculture, v.94, p.63-70, 2013. http://dx.doi.org/10.1002/jsfa.6191

Libânio, R. A. Cultivares e densidade de plantio em cultivo orgânico de tomate. Minas Gerais: UFLA, 2010, 65p. Doctoral Thesis

Maciel, G. M.; Silva, E. C. Proposta metodológica para quantificação de acilaçúcares em folíolos de tomateiro. Horticultura Brasileira, v.32, n.2, p.174-177, 2014. http://dx.doi.org/10.1590/hb.v32i2.306

Max, J. F. J.; Horst, W. J.; Mutwiwa, U. N.; Tantau, H. J. Effects of greenhouse cooling method on growth, fruit yield and quality of tomato (Solanum lycopersicum L.) in a tropical climate. Scientia Horticulturae, v.22, p.179-186, 2009. http://dx.doi.org/10.1016/j. scienta.2009.05.007

Oliveira, N. L. C.; Puiatti, M.; Bhering, A. S.; Cecon, P. R.; Santos, R. H. S.; Silva, G. C. C. Crescimento e produção da abobrinha em função de concentração e via de aplicação da urina de vaca. Revista Brasileira de Agropecuária Sustentável, v.3, p.129-136, 2013.

Reis, L. S.; Azevedo, C. A. V. de; Albuquerque, A. W.; Silva Júnior, J. F. Índice de área foliar e produtividade do tomate sob condições de ambiente protegido. Revista Brasileira de Engenharia Agrícola e Ambiental, v.17, p.386-391, 2013. http://dx.doi.org/10.1590/ S1415-43662013000400005

Rocha, M. Q.; Peil, R. M. N.; Cogo, C. M. Rendimento do tomate cereja em função do cacho floral e da concentração de nutrientes em hidroponia. Horticultura Brasileira, v.28, p.466-471, 2010. http:// dx.doi.org/10.1590/S0102-05362010000400015

Seufert, V.; Ramankutty, N.; Foley, J. A. Comparing the yields of organic and conventional agriculture. Nature, v.485, p.229-232, 2012. http://dx.doi.org/10.1038/nature11069 
Shirahige, F. H.; Melo, A. M. T.; Purquerio, L. F. V.; Carvalho, C. R. L.; Melo, P. C. T. Produtividade e qualidade de tomates Santa Cruz e Italiano em função do raleio de frutos. Horticultura Brasileira, v.28, p.292298, 2010. http://dx.doi.org/10.1590/S0102-05362010000300009

Silva, J. M.; Ferreira, R. S.; Melo, A. S. de; Suassuna, J. F.; Dutra, A. F.; Gomes, J. P. Cultivo do tomateiro em ambiente protegido sob diferentes taxas de reposição da evapotranspiração. Revista Brasileira de Engenharia Agrícola e Ambiental, v.17, p.40-46, 2013. http://dx.doi.org/10.1590/S1415-43662013000100006

Teruel, B. J. Controle automatizado de casas de vegetação: Variáveis climáticas e fertigação. Revista Brasileira de Engenharia Agrícola e Ambiental, v.14, p.237-245, 2010. http://dx.doi.org/10.1590/ S1415-43662010000300001
Toledo, D. S.; Costa, C. A.; Bacci, L.; Fernandes, L. A.; Souza, M. F. Production and quality of tomato fruits under organic management. Horticultura Brasileira, v.26, p.253-257, 2011. http://dx.doi.org/10.1590/S0102-05362011000200022

Willer, H.; Lernoud, J. The world of organic agriculture statistics and emerging trends 2016. Cap. The world of organic agriculture 2016: Key data on organic agriculture. FiBL and IFOAM. <http://www.organic-world.net/yearbook/yearbook-2016. html?L=\%2527A\%253D0>. 28 Mar. 2016.

Zandonadi, D. B.; Santos, M. P.; Medici, L. O.; Silva, J. Ação da matéria orgânica e suas frações sobre a fisiologia de hortaliças. Horticultura Brasileira, v.32, p.14-20, 2014. http://dx.doi. org/10.1590/S0102-05362014000100003 